\title{
Om den duelige kaptajn og skibets interesse
}

\section{Et kærlighedsdrama fra Aabenraa-søfartens storhedstid}

\section{Af MikKel Leth JeSPERSEN}

Livet ude på søen var tæt forbundet med livet derhjemme. Det fik kaptajn Christian Hohlmann at føle, da hans måde at forvalte skibet Java på kom til at koste ham forlovelsen med hans udkårne i 1866. Det forholdt sig nemlig således, at pigens fader, kaptajn Jes Peter Boysen fra Dyrhave på Løjt Land, også var medreder for Java, og han var langt fra tilfreds med Hohlmann. Historien står at læse $i$ en af Jes Peter Boysens brevbøger og giver et indblik i, hvordan en god sejlskibskaptajn burde agere. Han skulle nemlig ikke blot kunne navigere og sørge for vedligeholdelse af skibet, han skulle også kunne drive skibet som forretning og holde (med)rederne orienteret om sine dispositioner. For at være "en duelig kaptajn" skulle man varetage "skibets interesse «, som det hed $\mathrm{i}$ brevbogen. Den forholdsvis dramatiske historie om en forlovelse, der måtte opgives, er således indgangen til centrale aspekter af 1800-tallets søfartskultur.

\section{Indledning}

Den 14. januar 1866 sad den pensionerede sejlskibskaptajn Jes Peter Boysen (1806-1891) i sit hjem i Dyrhave på Løjt Land. Hvis man har besøgt området, kan man levende forestille sig, hvorledes han har ladet blikket glide ud over Aabenraa Fjord, mens han nøje overvejede indholdet af det brev, han var i færd med at skrive til sin ældste datter Margrethe. Det var en sag af største vigtighed, så han måtte vælge sine ord med omhu. Han ville have hende til at opgive ægteskabsplanerne med en mand, som han selv havde dårlige erfaringer med, og som han mente ikke ville være god for hende. Han ville dog nødigt fare for hårdt frem, så der kunne gå skår i deres forhold. Beslutningen skulle være hendes egen. Inden dagen var omme, var brevet færdigt og afsendt. Til trods for at indholdet var yderst privat og intimt, ind- 
førte han det $\mathrm{i}$ den brevbog, hvori han normalt kun kopierede sin forretningsmæssige korrespondance. ${ }^{1}$ I denne sag var det dog vanskeligt at adskille det private fra det forretningsmæssige, hvilket man får et indtryk af, når man læser, hvad han skrev til sin "kiære Grethe" i brevet, som her citeres i sin helhed:

"I gaar modtog vi dit brev af 8de denne [måned], og hvori du beder os om vores Tilladelse og Samtykke til din forlovelse med [Christian] Hohlmann, da dette nu er en Sag af største Vigtighed, saa ville vi hermed skriftlig tilskrive dig min Mening og raadføre dig til det bedste, uden dog derved at ville betage dig din frie Villie, thi du maae og skal selv raade i denne vigtige Sag.

Ieg har intet at udsætte paa Hohlmanns Person eller Charachter, men han er ingen duelig Skibsfører, og bliver det heller aldrig, da han slet ikke forstaaer at føre ordentlig Regnskab og omgaaes sparsommeligen med Pengene, af denne Aarsag er det en afgiordt Sag, at Hohlmann for fremtiden ikke faar Skibet Java at føre, med mindre at han indløser det hele Skib, og dertil har Hohlmann ingen Penge.

Hvorved ville nu vel Hohlmann ernære en Famielie Datter er vel dog nok værd at bringe i Overveielse ved en saadan vigtig Sag, thi det daglige Brød kommer sandligen ikke af sig selv, det er imod Guds sande og vare Ord at tænke saaledes, kun forst naar vi omgaaes vindskibeligen og sparsommeligen i det Kald, hvori Herren har sat os, da først kunne vi vente Herrens Velsignelse, hvorpaa alt beror.

Af denne Grund er det altsaa kiere Grethe, at ieg ikke med et glad og venligt Hierte kunne give dig mit Samtykke til din forlovelse med Hohlmann, men ieg vil dog hellere selv være den sørgende Deel, end som ieg ville betage dig din frie Villie, troer du da endnu kiere Grethe, at din Kierlighed til Hohlmann vil holde ud under alle Livets Sorger og Bekymringer, nu saa vælg selv i Herrens Navn, ieg skal da give mit Samtykke, thi ieg vil være fri for alt Ansvar, og du maae og skal selv raade i denne vigtige Sag, men tvende ufravigelige Betingelser vil ieg da ogsaa hermed giøre dig opmerksom paa, du maae for Fremtiden ikke komme og overøse mig med Klager, naar du skulde komme i trykkende Omstændigheder, thi dette ville ieg ikke kunne taale, den anden Betingelse er, du faar intet til Udstyr eller Medgift i rede Penge førend efter min og min kiere Kones Død, af hvad der da maae være tilovers af min liden formue skal du træde i Arv med mine øvrige Børn. Jeg har nu saaledes tilskrevet dig min rigtige mening, og du kunne være overbevist om, at dit sande Valg ligger mig meget paa Hierte." 


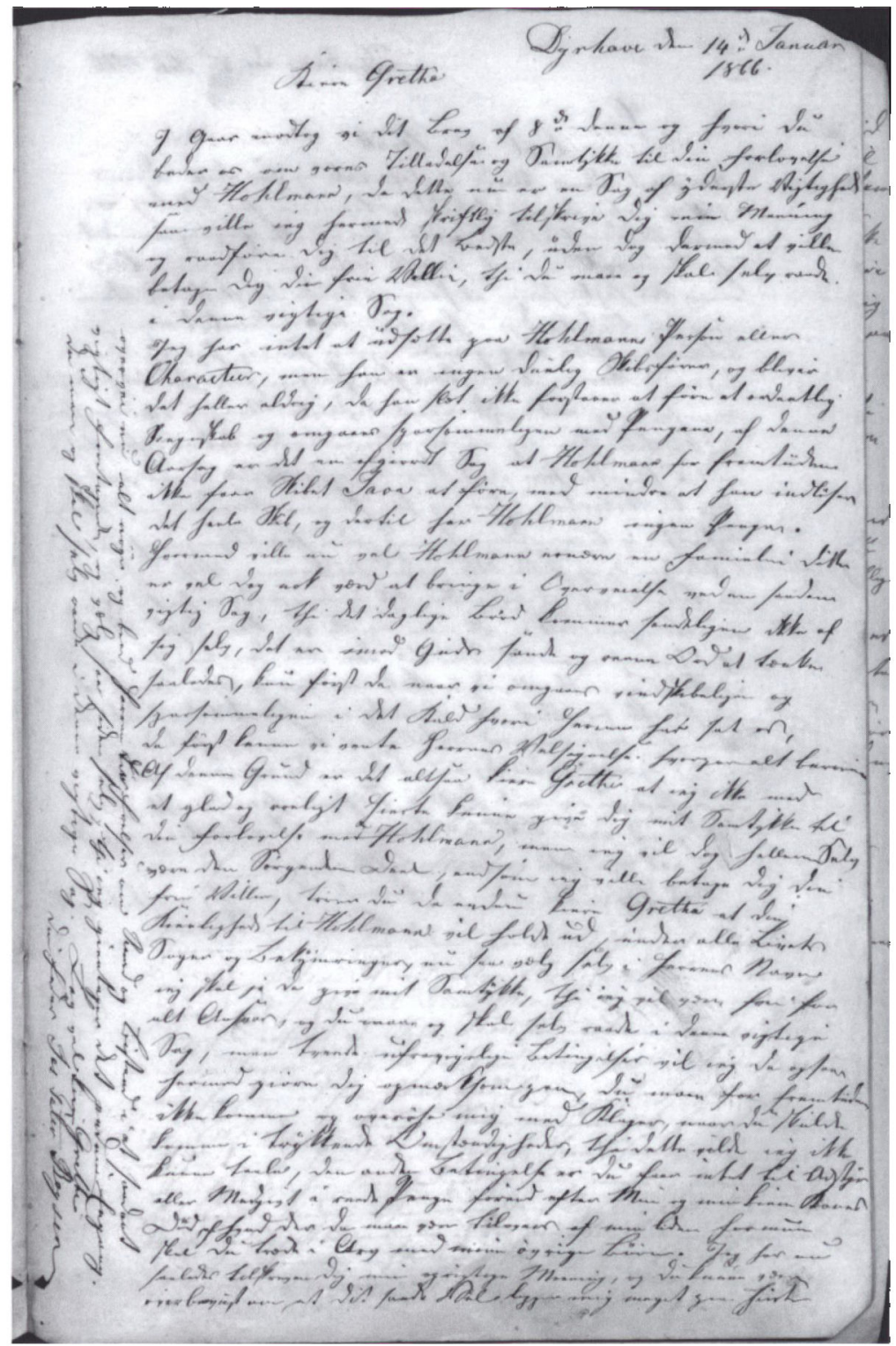

Fotografi af den side, hvor Jes Peter Boysen indforte brevet til sin datter Margrethe $i$ den ene af sine to bevarede kopibgger. Dette brev er omdrejningspunktet for denne artikel, men kopibogerne rummer en mængde af kaptajnens breve, som indeholder interessante oplysninger om livet til sas $i$ Aabenraa-søfartens blomstringstid $i$ 1800tallet Foto: Mikkel Leth Jespersen. 
Hvis budskabet ikke allerede var trængt ind hos datteren, gentog Jes Peter Boysen det endnu engang i de tre følgende linjer, som er tilføjet i brevbogens margin: „Overvej nu alt nøje, og beed Heren Vor Frelser om Raad og Bistand i et saadant vigtigt Foretagende, og vælg saa siden selv, thi ieg gientager det neden Engang. Du maa og skal selv raade $\mathrm{i}$ denne vigtige Sag." Brevet blev afsluttet med følgende hilsen: "Lev vel Kiere Grethe. Din Fader Jes Peter Boysen."

Normalt ville man vel levere et så følsomt budskab mundtligt, men Margrethe må have været borte fra hjemmet, siden Jes Peter Boysen blev nødt til at meddele hende sit svar per brev. Uanset de ydre omstændigheder har situationen efterladt en kilde, der giver et interessant indblik i Jes Peter Boysens stillingtagen til datterens ægteskabsplaner. Derudover giver brevbogen mulighed for at følge et forløb, der begyndte i 1860 og endte i et stejlt opgør mellem Jes Peter Boysen og Christian Hohlmann i januar måned 1866 - få dage før Jes Peter Boysen skrev brevet til sin datter. Konflikten havde både private og forretningsmæssige aspekter og endte efter alt at dømme med at få store konsekvenser for den ene af de to kaptajner. Forløbet af konflikten mellem kaptajnerne giver et indblik i 1800-tallets søfartskultur, som ikke kommer frem i de klassiske analyser af sejlruter, handelsvarer og skibsbygning eller kvantitative undersøgelser af søfolkenes sociale baggrund mv. I konflikter som denne formuleres de synspunkter og opfattelser, der normalt ikke kommer til udtryk. I en situation, hvor der hersker konsensus om de dispositioner, der foretages, behøver man ikke argumentere og forklare sine synspunkter og handlinger. Derfor giver kilderne fra et sådant konfliktforløb et sjældent perspektiv på den gamle søfartskultur - i brevene formuleres eksplicit udtrykte forventninger til, hvad det ville sige at være en duelig kaptajn, og hvordan man skulle varetage skibets interesse. I det omfang kaptajnernes tankegang hidtil er blevet beskrevet, er det primært i deres egne erindringer, men de har den store kildemæssige ulempe, at de er skrevet på efterhånd og derfor præget af efterrationaliseringer og glemsel. Brevbogen derimod giver et samtidigt blik ind i Jes Peter Boysens problemer, og hvordan han reagerede på dem.

\section{Jørgen Bruhns kaptajn}

Forfatteren til brevbogen og hovedperson i historien er kaptajn Jes Peter Boysen. Han blev født i Dyrhave på sydsiden af Løjt Land den 
14. september 1806. Hans fader Eschel Boysen var selv kaptajn, og hans moder, Margrethe (født Holdt), var kaptajnsdatter, ligeledes fra Dyrhave. Det er uvist, hvornår han præcis indledte sin karriere til søs, men han var styrmand på fregatten Cimber (I) i årene 1836-37. Året efter blev han kaptajn for det noget mindre skib skonnertbriggen Comet. Den 15. september dette år tog han borgerbrev som skipper $\mathrm{i}$ Aabenraa. Endelig blev han kaptajn for fregatskibet Creole i 1839 og fortsatte som fører af dette skib helt frem til 1849.2 Jes Peter Boysen tilhørte den generation af Løjt-kaptajner, der nød godt af de gode tider, som langfartssejladsen på Sydamerika sikrede for Aabenraa-søfarten i 1830'erne og 1840'erne. En stor del af æren for dette erhvervseventyr kan tilskrives den driftige og dygtige Jørgen Bruhn (17811858), der i løbet af 1830'erne ind tog positionen som områdets største reder. På havnen i Aabenraa fik han bygget det ene skib efter det andet, og i Rio de Janeiro blev han kendt som manden bag de smukke, hurtige og driftsikre sejlskibe fra Aabenraa. ${ }^{3}$

\section{Jes Peter Boysens karriere}

\begin{tabular}{llllll}
\hline År & Funktion & Skib & Type & Drægtighed & Rederi \\
\hline $1836-37$ & Styrmand & Cimber & Fregat & $1371 / 2 \mathrm{kmcl}$. & Jørgen Bruhn \\
1838 & Kaptajn & Comet & Skonnertbrig & $491 / 2 \mathrm{kmcl}$. & Jørgen Bruhn \\
$1839-1849$ & Kaptajn & Creole & Fregat & $149 \mathrm{kmcl}$. & Jørgen Bruhn \\
$1849-1851$ & Kaptajn & Canton & Fregat & $155 \mathrm{kmcl}$. & Jørgen Bruhn \\
$1852-1854$ & Kaptajn & Orion & Bark & $94 \mathrm{kmcl}$. & Richardt Richelsen \\
$1854-1859$ & Kaptajn & Cecrops & Fregat & $1711 / 2 \mathrm{kmcl}$. & Jørgen Bruhn \\
$1860-1864$ & $\begin{array}{l}\text { Kaptajn/ Java } \\
\text { medreder }\end{array}$ & Bark & $1541 / 2 \mathrm{kmcl}$. & Chr. Karberg \\
& & & & \\
\hline
\end{tabular}

Creole var en ældre fregat bygget i 1825. Ikke desto mindre havde det været stoltheden i Aabenraas handelsflåde langt op i 1830'erne. ${ }^{4}$ Til trods for at det nu var et aldrende fartøj, var det formentlig ikke uden en vis ærefrygt, at Jes Peter Boysen gik om bord som dets kaptajn i 1839. Ifølge kaptajn Hans Bruhns erindringer kom Jes Peter Boysen til at tjene mange penge med Creole. Ti år blev det til, inden han i efteråret 1849 blev kaptajn for et andet af Jørgen Bruhns skibe, nemlig fregatten Canton. Det havde ligeledes været et af de største og hurtigste skibe i Aabenraa-flåden, da det løb af stablen i 1838 under navnet Dan..$^{5}$ Det var det tredje af Jørgen Bruhns skibe, som Jes Peter Boysen kom til at føre, så det er tydeligt at se, hvorledes hans karriere var knyttet til matado- 
rens erhvervsmæssige succes. Hjemme i Dyrhave blev den fine karriere belønnet med et ægteskab med kaptajnsdatteren Christina Maria Matthiessen, som Jes Peter Boysen blev gift med i 1840. Parret fik i alt fire børn; de to døtre Margrethe (1845-1913) og Ellen (1853-1926) og de to sønner Eschel (1848-1921) og Johannes Conrad (1851-1886). ${ }^{6}$

Ved overtagelsen af skibet Canton i 1849 påbegyndte Jes Peter Boysen den første af de to brevbøger, der er bevaret fra hans hånd. Heri kopierede han sin forretningsmæssige korrespondance. Den første bog dækker tiden frem til 1856 og den anden tiden derfra og frem til 1875. De er primært ført på dansk, men indeholder også breve på tysk og engelsk. Det første brev i den ældste af bøgerne er skrevet den 14. september 1849 i Falmouth og er skrevet til Jørgen Bruhn. Allerede her får man et godt indtryk af kaptajngerningens to elementer, den forretningsmæssige drift og navigationen:

"I gaar Aften Ankom hertil over Hull i fem Dage, og haver nu i dag modtaget Skibet Canton med alt Tilbehør og som synes at være i en god Tilstand, og fuldstændig Udrustet, og i morgen tidlig agter [jeg] at gaae til Søes og efter Aftale først til Vigo, som vist vil være rigtigst, og skal da $\mathrm{i}$ enhver henseende sørge for Skibets Interesse. I øvrigt haver ieg modtaget af Capt. H. Bruhn alle Søekort og Bøger efter samme Taxation, som han haver imodtaget dem efter Capt. Maag, og denne Sum bliver ieg ham Skyldig. Paa omstaaende Side Regning over modtaget Penge. Slutter med venskabelig Hilsen til Dem og Familie fra deres forbundne Ven og Tiener. Jes Peter Boysen « (14. september 1849).

Begrebet skibets interesse går igen i Jes Peter Boysens brevbøger, og det betegner kaptajnens pligt til at varetage den forretningsmæssige drift af skibet til fordel for redere og andre interessenter. Det ville forst og fremmest sige kaptajnen selv, da han modtog såkaldt kaplak, hvilket som regel var $5 \%$ af skibets indtjening. Ud over navigeringen af skibet var det således vigtigt, at kaptajnen forstod sig på handel og kunne føre regnskab samtidig med, at han skulle kunne kommunikere med forretningspartnere, hvilket som regel foregik på tysk og engelsk. Når navigationen svigtede, kunne alt andet dog være lige meget. Det oplevede Jes Peter Boysen natten mellem den 30. og 31. januar 1852, da Canton totalforliste på et koralrev i det nordlige Stillehav. Da var Jes Peter Boysens karriere som kaptajn tæt på at slutte brat. Det lykkedes at redde hele besætningen, men det var ikke nogen let hjemkomst for den altid så pligtopfyldende Jes Peter Boysen, hvilket fremgår af hans brev til Jørgen Bruhn: 
»Det smerter mig, at ieg skulde være saa uheldig nu at forliise Skibet aldeles, efter at det nu var blevet sat $i$ en saa fuldkommen Tilstand, maatte De dog have haft det godt forsikret, dette ville ieg ønske, og at Deres andre Skibe snart maatte indhente den tabte Skade af deres gode Skib Canton « (24. februar 1852).

Ved ankomsten til London den 9. august 1852 erfarede Jes Peter Boysen dog, at Jørgen Bruhn ikke havde haft skibet forsikret, hvilket ikke fik hans situation til at se lysere ud. Et totalforlis var i sig selv en katastrofe for enhver kaptajn. Det var en uskreven regel inden for søfarten, at en kaptajn var den sidste til at forlade den synkende skude, og derfor var chancerne for at overleve små, og hvis man overlevede, mens medlemmer af besætningen døde på skibet, så det ikke godt ud. I denne situation, hvor alle mand havde overlevet forliset, var det formentlig Jes Peter Boysens store bekymring, om han nogensinde ville blive betroet et skib igen. Disse bekymringer hjalp Jørgen Bruhn ham ikke ud af, men gav ham et håb, idet han skrev om forliset, "at det vel med Tiden kunne blive glemt" (9. august 1852).

Jes Peter Boysen fik da heller ikke overdraget kommandoen over et andet af Jørgen Bruhns skibe ved hjemkomsten. I stedet var han så heldig, at hans gode ven kaptajn Richardt Richelsen (1786-1864), der i sin tid havde anbefalet Jes Peter Boysens borgerskab i Aabenraa, og en kreds af medredere overdrog ham barkskibet Orion på 94 kommercelæster ( $\mathrm{kmcl}$.). Det var godt $50 \mathrm{kmcl}$. mindre end Canton og derfor et karrieremæssigt tilbageskridt, men udnævnelsen må have været en lettelse for Jes Peter Boysen, som nu kunne fortsætte den ellers forliste karriere. Frem til efteråret 1854 sejlede Jes Peter Boysen for $» R$. Richelsen og Medredere", men ved denne tid havde Jørgen Bruhn "glemt" Jes Peter Boysens totalforlis med Canton, og i november 1854 var Boysen tilbage i den mægtige Aabenraa-matadors tjeneste. Han fik nu overdraget den $171^{1} / 2 \mathrm{kmcl}$. store fregat Cecrops, som han førte i knap fem år til efter Jørgen Bruhns død $\mathrm{i}$ foråret 1858.

I forsommeren 1859 efterlod Jes Peter Boysen Cecrops i London og rejste over Hamborg hjem til Dyrhave. I et senere brev hævder han, at han af rederiet Jørgen Bruhns Sønner nærmest var blevet lovet fregatten Cimber (II), som var Aabenraa-flådens største og alle tiders mest berømte skib. Det blev dog ikke til noget, og i det hele taget synes hans samarbejde med Bruhn-dynastiet nu at ophøre. I stedet kom han til at tilbringe vinteren hjemme på Løjt som arbejdsløs kaptajn. Det huede ham ikke, og da han igen indførte et brev $\mathrm{i}$ kopibogen, 
fremgår det, at han lå $\mathrm{i}$ to forskellige forhandlingsforløb om investeringer $i$ to forskellige skibe, hvoraf det ene gerne skulle bringe ham tilbage på søen inden længe.

\section{Rederiet af Java}

Resultatet af de forskellige forhandlinger endte med et samarbejde om et skib med Sønderborg-matadoren Christian Karberg (18041896). Han kom ud af et af Sønderborgs største rederdynastier, og i 1860 ejede han en betydelig andel af Sønderborgs sejlskibsflåde med seks større sejlskibe på søen. ${ }^{7}$ Samtidig var han købmand, godsejer og engageret i lokalpolitik. Det var hans rederkontor, der skulle stå for skibets korrespondance, hvilket blandt andet ville sige modtagelse af indtjeningen, bogføringen og forsikring.

Det var ved samme tid, at Jes Peter Boysen første gang kom i kontakt med Christian Hohlmann, som var parat til at købe en fjerdedel af skibet til gengæld for at blive førstestyrmand om bord. Han stammede fra Løjt Kloster, hvor han var blevet født den 20. december 1831, og var således 28 år gammel, da han indgik samarbejde med Jes Peter Boysen i foråret 1860. Hvor Christian Hohlmann hidtil havde været beskæftiget, og hvordan han havde tjent sine penge, er uvist, men han var ikke ud af kaptajnsslægt. Hans ældre broder Nis Hohlmann havde dog gjort karriere som kaptajn i sin svigerfader Jacob Bendixens rederi. Han klarede sig rigtig godt og byggede kaptajnsgården Valhalla, hvor han nu levede som rentier. ${ }^{8}$ Det var muligvis Nis Hohlmann, der havde hjulpet den 16 år yngre broder frem inden for søfarten. I et senere brev fra Jes Peter Boysen oplyses det, at Christian Hohlmann "er jo intet Sted Borger « (21. september 1865), så hvor han egentlig havde hjemme, er uklart. Hans ønske om at ville deltage i det nye skib må have vakt stor glæde hos Jes Peter Boysen, der gerne ville til søs igen så snart som overhovedet muligt.

Skibet, som Jes Peter Boysen var ude efter, var bygget på spekulation, altså uden forudgående bestilling, og stod nu bilfærdigt (dvs. alt træarbejdet var afsluttet, men der manglede udrustning med sejl, tov, spil, inventar etc. ${ }^{9}$ ) på Reimers værft i Aabenraa. Det kunne nu købes til en fordelagtig pris, så Jes Peter Boysen havde afsluttet handlen under den forudsætning, at han kunne optage det nødvendige lån $\mathrm{i}$ Hamborg. Det var tilsyneladende blevet aftalt, at hver af de tre redere skulle eje en tredjedel af skibet. Han havde selv 11.000 mark, mens 


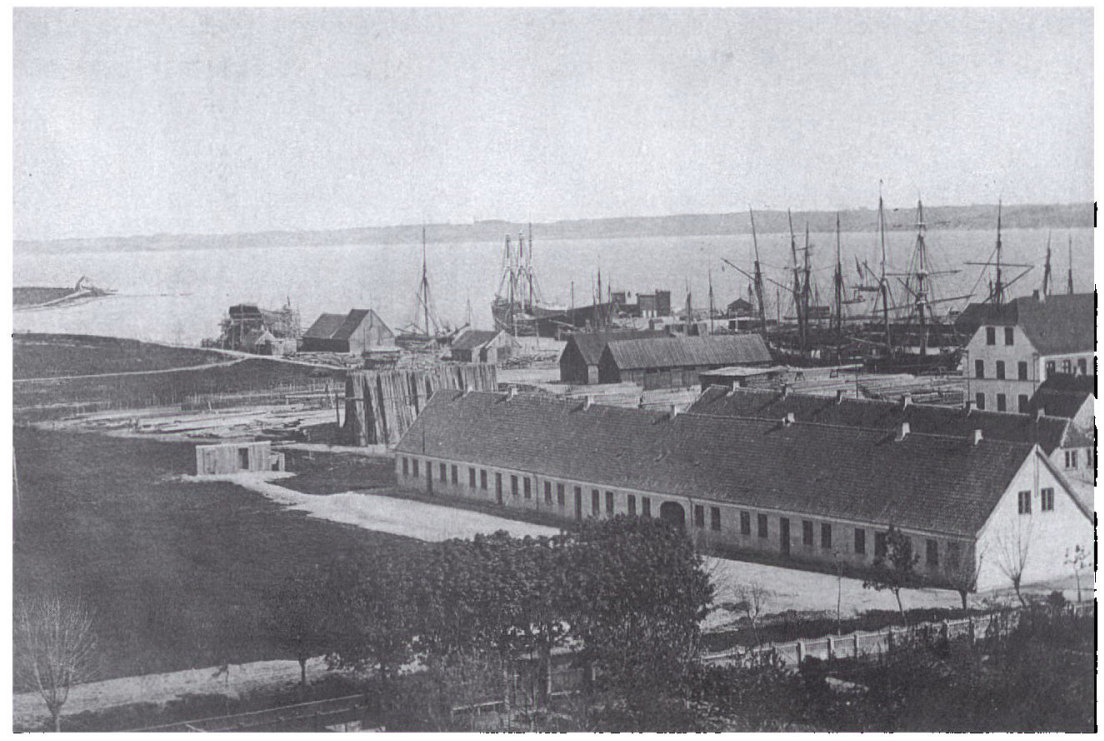

Fotografi af Aabenraa Havn i 1865. Det er således fra den tid, da byens skibsværfter blomstrede. Til venstre $i$ billedet ses Reimers varft, hvor Java var blevet bygget omkring fem à tidligere. Det er det eneste billede, der er overleveret af værftet, som blev Aabenraas fjerde, da det abnede i 1855-56. Foto: Museum Sonderjylland-Kulturhistorie Aabenraa.

Christian Hohlmann havde 15.000 mark, og han regnede med, at skibet ville komme til at koste $i$ alt 60.000 mark. Som medejende styrmand skulle Christian Holhmann have de $1 \frac{1}{2}$ af Jes Peter Boysens $5 \%$ kaplak. Det lykkedes at skaffe finansieringen, og snart var skibets kommende kaptajn i fuld gang med at bringe det fra bilfærdigt til sejlklart. Den 14. juli 1860 løb skibet af stablen og fik navnet Java, men hvor det i første omgang blev hjemmehørende var allerede i samtiden lidt uklart, da man i skibslisterne i Mercantil-Calenderen for 1862 har placeret Java under Aabenraa, til trods for at Christian Karberg i Sønderborg er angivet som hovedreder. Jes Peter Boysen står som skibets kaptajn. ${ }^{10}$ I 1864 var Java blevet overført til skibslisten for Sønderborg. ${ }^{11}$

Efter en forholdsvis besværlig og langsommelig rejse kunne Jes Peter Boysen meddele Christian Karberg Javas lykkelige ankomst til Batavia den 27. marts. Skibet havde holdt tæt, sejlede til kaptajnens tilfredshed og alt var vel om bord. Efter en del besvær i havnen gik Java videre fra Batavia til Sourabaya, men på denne tur var Christian 
Hohlmann blevet meget syg, og Jes Peter Boysen havde besluttet at bringe ham i land i Samarang. Her efterlod man styrmanden på hospitalet, hvor han lå bevidstløs i flere dage, mens Java sejlede videre til Sourabaya. Jes Peter Boysen kunne nu berette om »styrmand Hohlmanns Hospitals Regning og Reisen med Dampbaaden til Sourabaya [som kostede] over 100 Gylden, og han er endnu ikke gandske rask, nemlig Fødderne op til Knæene er gandske opsvolen og saa tykke, at han ingen Fodtøj kunne bruge, haaber dog at det vil gaa over uden videre Omkostning “ (11. juni 1861). Det er første gang, Jes Peter Boysen omtaler sin styrmand, og man bemærker, at det var omkostningerne ved Christian Hohlmanns sygdom, der bekymrede ham, og ikke styrmandens helbred. Samme ærgrelse findes også i senere breve. Nogen egentlig misstemning mellem de to omtaler Jes Peter Boysens dog ikke.

Derefter sejlede Java rundt i Fjernøsten frem til forsommeren 1863. Ifølge kaptajnens breve til Christian Karberg i Sønderborg gik det, som det skulle. Skibet vandt et godt ry hos de kinesiske købmænd, der befragtede de europæiske skibe, og det var ikke svært for Jes Peter Boysen at få gode månedsfragter (18. august 1861). På et tidspunkt fortæller han om englændernes diskrimination af danske og tyske skibe, som han forklarede med, at de kinesiske købmænd foretrak skibe fra disse to nationer, da de modsat englænderne behandlede kineserne som mennesker (14. juni 1862). Senere $\mathrm{i}$ århundredet fortælles det tilsvarende, at kineserne havde en højere agtelse for tyskerne end andre nationer, da tyskerne generelt behandlede dem venligere og uden vestlig arrogance. ${ }^{12}$ I $1860^{\prime}$ erne gjaldt det øjensynligt også danskerne.

Java tjente mange penge, men det blev stadig sværere at få gode månedsfragter, da sejlskibene blev udkonkurreret af dampskibe på flere strækninger. Ifølge Jes Peter Boysen kunne damperne sejle en rute tre gange, mens sejlskibene kun nåede en tur. Befragterne øgede hele tiden presset på kaptajnerne for at få dem til at sejle til havne, der ikke var åbne for europæiske skibe ifølge traktaterne. Denne ulovlige sejlads indebar risiko for sanktioner fra britiske og kinesiske myndigheder. I august 1862 begyndte kaptajnen så småt at planlægge hjemrejsen det følgende år (28. august 1862).

I Sønderborg var Christian Karberg øjensynlig ikke begejstret for Jes Peter Boysens planer om at vende hjem i løbet af 1863. Over for sin medreder begrundede kaptajnen sin beslutning med henvisning 
til skibets interesse. Ud over det forhold, at fragterne blev stadig dårligere, så mente han, at det var på tide for besætningen at vende hjem. De folk, man kunne hyre ude i Shanghai, var både dyre og dårlige, »fra Hongkong kunde man nok have et Mandskab noget billigere, men de løber da bort eller rettere sagt gaar bort, førend at den første Maaned er tilende, og der er intet at udrette med Tvangsmidler imod saadanne Banditter, vel haver vi ingen Bestemmelser, som siger, hvorlenge vi kunne beholde Mandskabet ombord, men nu næsten efter tre Aars forløb, at tvinge dem til at blive ombord længere mod deres Villie, dette kan ieg ikke, og det vilde ei heller være overensstemmende med den Lov, som siger os at handle imod vor Næste, saaledes som vi selv i Lignende Omstændigheder ville onske at blive behandlet. Mit Mandskab er et udsøgt Mandskab, som næsten alle have Navigation og gode Skolekundskaber, og som nu er duelige nok til at kunde betræde et hvilket som helst Skib i den Egenskab som Styrmand, og som fortiener at forfremmes ..." (24. januar 1863).

Bortset fra de allerede omtalte tilfælde nævnes Christian Hohlmann kun sjældent i Jes Peter Boysens breve, men så pludselig i sit sidste brev hjem inden afrejsen mod Europa meddeler kaptajnen, "Styrmand Hohlmann kan ieg siden anbefale som Fører af Java for Fremtiden«. Jes Peter Boysen havde øjensynlig selv tænkt sig at gå i land efter ankomsten til Europa. Han bad Christian Karberg sende et brev om hans holdning til dette spørgsmål, som kaptajnen ville modtage straks ved ankomsten til London (8. april 1863). Det var således Jes Peter Boysen selv, der banede vejen for, at Christian Hohlmann kunne overtage kommandoen over Java.

\section{Kaptajn Hohlmann}

Jes Peter Boysens indstilling af Christian Hohlmann blev efter alt at dømme godkendt af Christian Karberg, og efter ankomsten til London overtog styrmanden Java. Og nu skete der noget mærkværdigt, for knap var overdragelsen sket, før Jes Peter Boysen lod Karberg vide, at han og Hohlmann ikke havde haft et godt forhold under deres treårige rejse til Østen:

"Forholdet mellem mig og Hohlmann har (mellem os sagt) heele tiden langtfra ikke været saaledes, som det burde have været, men dette har slet ikke noget at gøre med Holhmanns Charakter eller Duelighed som Skibsfører, men ieg henholder mig bestemt til, hvad ieg 
førhen haver skrevet dem til om ham, og tvivler ieg slet ikke paa, at nu da alt Ansvar vil komme til at hvile paa ham, at han vil blive en meget opmærksom, forsigtig og duelig Skibsfører, men det er vist nok af denne Aarsag, at Hohlmann af egen frie Villie har tilbudt mig, at han nok vilde overtage min heele Andeel, nu her i London har ieg sagt ham, at ieg nok vilde overlade ham det halve af min Andeel, og paa Betingelser, som ieg tror, vi nok ville blive enige om, og hvis dette skulde komme til Afgørelse, haaber ieg ikke, at De vil have noget derimod. Ingen af os to reiser Hiem førend at en anden Befragtning er afsluttet, heele Mandskabet er afbetalt og de sidste reiser Hiem herfra i dag ... (2. september 1863).

Disse informationer ville Christian Karberg formentlig gerne have haft, inden Java var blevet overdraget til den nye kaptajn, og det forekommer derfor uforståeligt, at Jes Peter Boysen først nu fortalte sin medreder om problemerne. Der findes dog ingen spor af bebrejdelse fra Karberg i kilderne, og man fortsatte som planlagt. Derudover solgte Jes Peter Boysen halvdelen af sin tredjedel i Java til Christian Hohlmann, således at den nye kaptajn nu ejede halvdelen af skibet, mens den gamle kaptajn sad tilbage med en sjettedel. Prisen for den handlede sjettedel var 10.000 mark, så skibet blev fortsat anset for at være de 60.000 mark værd, som det i sin tid var blevet købt for (7. september 1863). Christian Karberg fungerede også som pengeinstitut for sine kaptajner, så det var hos ham, at Christian Hohlmanns penge skulle overføres til Jes Peter Boysen konto. Da handlen var gået i orden, sluttede Jes Peter Boysen en fragt til Fjernøsten og rejste derefter hjem til Løjt. Han ville blive fulgt af Christian Hohlmann, hvis der nåede at ankomme en ny styrmand fra Aabenraa, da hans tilstedeværelse i London i så tilfælde ikke ville være påkrævet. Den nybagte kaptajn nåede dog tilsyneladende ikke hjem, før Java atter afsejlede mod Østen (23. september 1863).

Hjemme i det dansk-tyske grænseområde trak det op til krig, og i januar 1864 skrev Jes Peter Boysen til Christian Hohlmann, som var på vej mod Shanghai. Den unge kaptajn havde ikke ladet høre fra sig, siden afsejlingen fra London i oktober året forinden. Jes Peter Boysens primære ærinde var at informere om den krig, der var under optræk, og som kunne få alvorlige følger for den danske skibsfart i Kina. Han fortalte, at det ikke så godt ud, da kongen pludselig var død, hvorefter de tyske forbundstropper havde besat Holsten. $\mathrm{Nu}$ truede de Danmark med krig. Hvis det skulle blive tilfældet, mente Jes Peter 


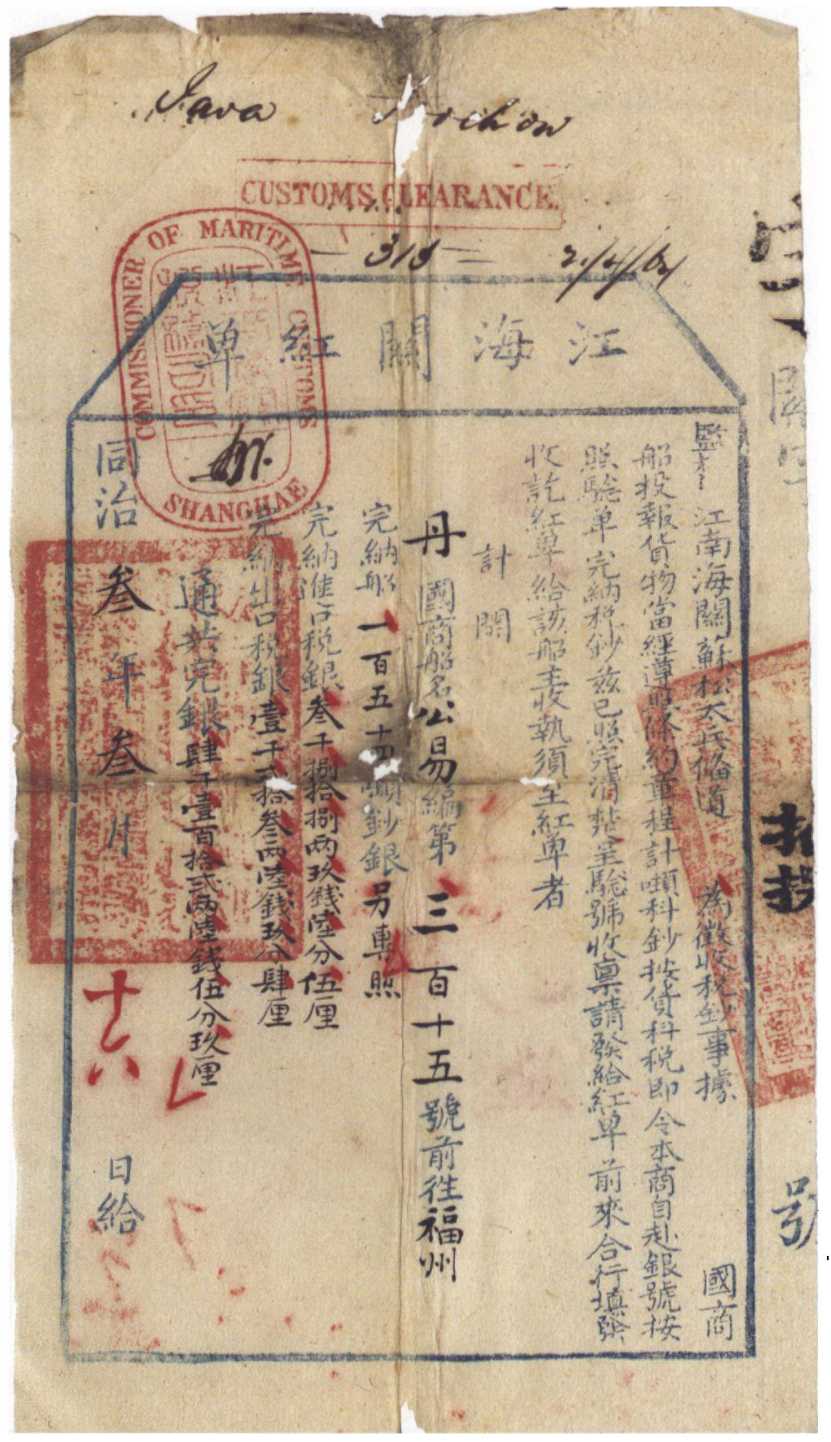

Den 21. april 1864 betalte Christian Hohlmann told af en ladning varer $i$ Shanghai, som skulle sejles til Foochow. Listen over varerne var skrevet på engelsk og fortæller, at der var tale om en meget blandet last, der blandt andet bestod af olie, silke og te. Kvitteringen for den betalte told var derimod på kinesisk og blev efterfolgende afleveret på byens danske konsulat, $i$ hvis arkiv den er bevaret på Rigsarkivet. Den er et vidnesbyrd om, hvor fremmedartet en verden, kaptajnerne skulle agere $i$. Trods deres gode sprogkundskaber kunne de vel næppe læse, hvad der stod på en kvittering som denne. Foto: Mikkel Leth Jespersen. 
Boysen, at det kunne blive et problem for »det danske Flag« i Kina, at skibene ville blive opbragt af preussiske orlogsskibe i området, da Danmark ikke havde orlogsskibe derude til at beskytte flaget. Han kunne dog ikke give Hohlmann nogen forholdsregler, men rådede kaptajnen til at handle efter bedste overbevisning og til at rådføre sig med Christian Karberg. Brevet afsluttes med en nytårshilsen fra kaptajnens »oprigtige« ven (7. januar 1864). Kun en gang nævnes krigen atter i brevene, nemlig i august 1864, hvor Christian Hohlmann ifølge sin broder havde været bekymret for opbringelse af den preussiske korvet Gazelle, men den blev ikke noget problem for Java (23. august 1864). Krigsskibet tog i stedet to andre af Christian Karbergs skibe, nemlig skonnerterne Chin Chin og Falk. ${ }^{13}$

Først i maj måned fik Jes Peter Boysen svar fra Christian Hohlmann, som han en uge senere refererede $i$ et brev til Christian Karberg. Java havde haft en temmelig hård rejse, men alt var vel om bord bortset fra, at "... Drengen Hans Schmidt var falden overbord fra Formærseraaen, en stor Sorg for hans Moder, da han var hendes eneste Barn, hendes Mand blev for nogle Aar siden knust af en Styrtsøe ombord i Briggen Sidon paa Reisen om Cap de Horn." Det var ofte drengene, der blev sendt op i masterne, og det forekom derfor med jævne mellemrum, at en skibsdreng døde på sin første langtur. Ulykken afspejlede de barske realiteter i den gamle søfartskultur. ${ }^{14}$ Brevet afsluttede Jes Peter Boysen med følgende bøn: »fremdeles ønsker ieg gierne saasnart som det skulle kunne lade sig giøre, at have mine Aftegninger eller Billeder af Java tilsendte . Der var muligvis tale om nogle af de endnu bevarede portrætter af skibet, som Christian Karberg tilsyneladende havde ladet fremstille til sin kaptajn (25. maj 1864).

Herefter var det gennemgående emne for korrespondancen problemer med Christian Hohlmanns udførelse af kaptajnsgerningen. Det begyndte $\mathrm{i}$ august måned, hvor Jes Peter Boysen måtte en tur ind forbi broderen Nis Hohlmann for at høre nyt. Karberg burde ellers være blevet orienteret om skibets sejlads og forretninger af kaptajnen selv, mente Jes Peter Boysen, "og at han ikke ved Ankomsten, Afseilingen, Fragtslutninger osv. skriver Dem til og sender dem Afregningen, det vil jo nu være nødvendig for Dem, at give ham en Paamindelse om denne hans Pligtopfyldelse, skulle de imidlertiid faa Brev fra ham eller hører noget videre om Java, beder ieg dem at meddele mig samme“ (23. august 1864). Det grundlæggende problem på 
dette tidspunkt var Christian Hohlmanns manglende meddelsomhed, da de to hjemmeværende medredere naturligvis havde en stor interesse $\mathrm{i}$ at høre, hvordan det gik med det skib, som de havde investeret mange penge i. At Jes Peter Boysen skulle gå til kaptajnens broder for at høre nyt, var helt utilstedeligt.

Det blev ikke bedre i resten af 1864 . I november var det fortsat Nis Hohlmann, der var bedst orienteret om Javas sejlads, og Jes Peter Boysen beklagede sig til Karberg: "Det er nu en meget lang Tiid siden, ieg haver hørt noget fra Capt. Chr. Hohlmann eller fra Skibet Java, men sandsynlig har De jo vist heller ikke havt noget Brev «. Sidste nyt om Java havde Jes Peter Boysen fra et brev, som kaptajnen havde skrevet til sin broder Nis Hohlmann af den 25. juli. Af dette brev fremgik det, at Christian Hohlmann havde afsluttet en fragt til $3.100 \$$ med en kineser i Foochow. Jes Peter Boysen mente, at det var en meget ringe fragt, men dog bedre end at ligge stille. Han vidste heller intet om antallet af liggedage eller betalingen, da "stor Forsigtighed er derhos nødvendig, thi finder Chineserne, at de have med en Mand at giøre, som de letteligen kunne bedrage, da skammer sig de heller ikke ved at giøre det « (29. november 1864). I december måned havde Karberg modtaget et "Charterparty" (en fragtkontrakt) for ovennævnte aftale, men heller ikke han havde fået brev fra Christian Hohlmann, og nu fik Jes Peter Boysens frustrationer frit løb:

"... hvad der kan være Aarsag til en saadan Handlemaade af ham, kan ieg slet ikke begribe, da han ikke kan være uvidende om hans Pligts Opfyldelse i denne Retning, thi medens han foer med mig som Styrmand fik han bestandigen paa enhver Plads alle Skibsregninger til Afkopiering og fik at vide, hvilke af samme ved Afseilingen fra Enhver Plads var at hiemsende til Regenskabsføreren, dog en Art Lethed eller Ligegyldighed kunde ieg jo ogsaa nok denne Gang bemærke fra ham, men ieg troede fast, at naar han fik selv Comandoen, at dette nok skulle ændre sig, da han ellers er retskaffen nok i hans Handlemaade, og har ogsaa Kundskaber nok, naar han blot vilde bruge denne rigtigen, og nærværende Charterparty viser jo tydeligen nok denne Lethed og Ligegyldighed, som beherske ham, thi i dette er der slet ingen Sikkerhed for Fragtbetalingen, da Java sandsynlig vil blive sendt fra Cheefoo til Foochow i Ballast, saa vi jo let kunne tabe heele Fragten, dog ville vi haabe det bedste, da der også gives mange Chineserer, som ikke tænker paa at bedrage ..." (december 1864).

Vedlagt brevet var en skrivelse til Karbergs regnskabsfører hr. Iver- 


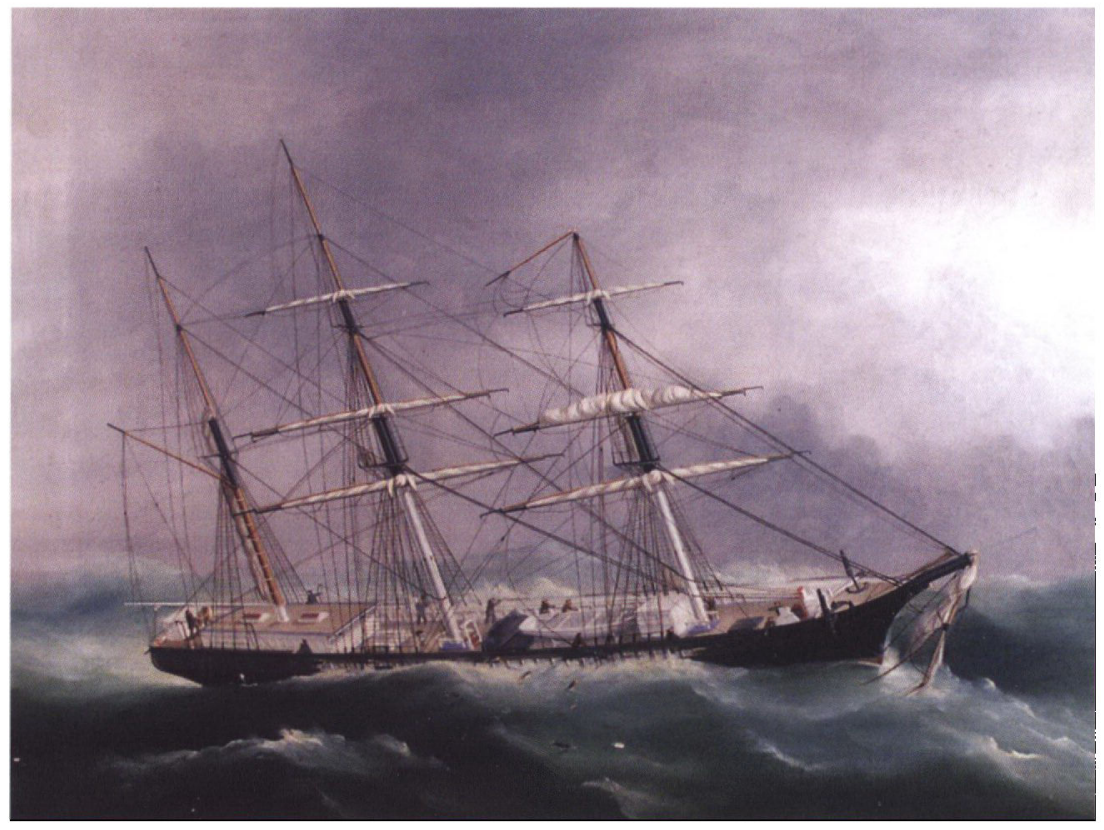

Signeret og dateret skibsportræt af barken Java $i$ havsnød. Det er malet af den anerkendte britiske skibsportrætmaler Frederik Tudgay (1841-1921) i 1863. Det er et säkaldt situationsbillede, der skal vise skibet i en konkret situation, som det har befundet sig $i$. Billedet er af høj kunstnerisk kvalitet og viser et væld af detaljer $i$ forbindelse med besatningens bestrabelser på at redde skibet. Foto: Museum SonderjyllandKulturhistorie Aabenraa.

sen. I dette brev uddybede Jes Peter Boysen, hvorledes forholdet mellem ham og Christian Hohlmann havde været $\mathrm{i}$ de tre år, de havde sejlet sammen:

"Fra $\mathrm{H}$ : hører jo ikke noget, og dette er ret slemt og ikke at forstaa, der er dog et besynderligt Menneske, og du kunne troe kiere Iversen, at ieg har havt et svært Liv i Omgangsmaaden med denne Mand i de 3 Aar, vi farede tilsammen, da han var meget Lunefuld og fandt sig meget let fornærmet, mange Gang kunde ieg slet ikke udgrunde Aarsagen til denne hans Vrede imod mig, da han til saadanne Tider slet ikke vilde tale med mig eller sige mig Aarsagen, et ganske besynderligt Menneske, men ethvert Menneske have jo sine feil, og er Hohlmann i øvrigt intet slet Menneske, saa ieg havde ingen Grund til at kunne misrecommendere ham, men ieg troede derimod fast, at naar han selv fik Commandoen med den halve del i Skibet, at han vilde 
have bleven en meget opmærksom og duelig Mand, men ieg frygter nu for at Ligegyldigheden og Uefteretligheden hos ham, snarere har tiltaget, og at han slet ikke føre noget ordentligt Regnskab, dog maaske det endnu kunne forandre sig til det bedre, og som ieg dog endnu ville haabe.«

Når man læser dette brev, bliver forundringen over, at Jes Peter Boysen ikke advarede Christian Karberg mod at indsætte den vanskelige styrmand som kaptajn, men tværtimod anbefalede ham, større. De to var jo tydeligvis ikke enige om, hvordan skibet skulle føres, og det lader til, at der flere gange har været åben uvilje mellem dem. I det nye år hørte Jes Peter Boysen og Christian Karberg fortsat ikke fra Java, men den 23. januar kunne Boysen meddele Karberg, at han havde haft besøg af Nis Holhmann, der havde modtaget et brev fra sin yngre broder dateret den 17. november. Jes Peter Boysen havde læst brevet, hvori Christian Hohlmann beklagede sig over, at han ikke havde hørt mere fra Karberg. Ifølge Jes Peter Boysen var det dog ikke en rimelig grund til kaptajnens ligegyldige fremgangsmåde. Ellers var alt angiveligt vel om bord, selvom det var dårlige tider for fragtsejladsen (23. januar 1865).

\section{Styrmand Andresen tager over}

Ifølge det næste brev til Christian Karberg dateret den 21. januar (hvilket formentlig skal være 21. februar for at brevet passer ind i brevbogens kronologi) var situationen den samme, og Jes Peter Boysen mente, at det snart var nødvendigt "at gribe til andre Udveie«. Familien havde heller ikke hørt fra Christian Hohlmann, men nu verserede det rygte, at han havde overladt Java til skibets styrmand, Jes Andresen, og at kaptajnen selv var på vej hjem til Aabenraa. Da ingen havde hørt fra Hohlmann, kom rygtet naturligvis ikke fra ham, men fra Jes Andresen og en kaptajn Backmann, der havde været sammen med Hohlmann i Kina.

Endelig den 24. marts 1865 fremgår det, at Jes Peter Boysen har modtaget et brev, som kort tid forinden var ankommet til Christian Karberg fra Christian Hohlmann. Det indeholdt ingen undskyldning for kaptajnens ligegyldighed med hensyn til at rapportere hjem om Java. Derudover fremgår det, at der var blevet brugt mange penge, som Hohlmann ikke havde gjort rede for; »[jeg] haaber dog nu, da Hohlmann nu kommer hiem, at alt dette vil komme i Orden og faa 
sin Rigtighed «, skrev Jes Peter Boysen. Dernæst fulgte hans positive vurdering af den ændring, der var sket på kaptajnsposten, da han havde et godt indtryk af Jes Andresen:

"i øvrigt troer ieg ikke, vi vil komme til at fortryde den Forandring, som er skeet med Skibsføreren af Java, denne Jes Andresen, [der] hører Hiemme her i Løit, har Ord for at være en duelig og retskaffen Mand, har faret fra Dreng af i Agent [Jørgen] Bruhns Employ [tjeneste], blev meget ung Capt. og stod en Tiid meget høit anskreven hos dette Contor, men faldt senere hen i Unaade og blev afskediget, senere gik han nu ud som Styrmand med det store Skib Cimber[s] første Reise, og blev igien afskediget fra samme paa Vestkysten, men ieg var selv denne Gang samtlig med dette Skib i Sanfrancisco og troer, at Skylden var mere paa Captains Side, siden denne Tiid har han været uden Employ, indtil han besluttede at gaa Employsøgende ud til China med Capt. Nissen forrige Aar, og ieg haaber, at denne Mand vil varetage Skibets Interesse.«

Skudsmålet indeholder en interessant beretning om en Aabenraakaptajns op- og nedture, samtidig med at Jes Peter Boysen endnu engang bruger begrebet varetagelse af skibets interesse som et kriterium for at være en god kaptajn. At han anså den nye kaptajn for en forbedring, var ikke ensbetydende med, at han var tilfreds med måden, hvorpå Christian Hohlmann havde foretaget skiftet. Det skriver han til Karberg i april, hvor man dagligt ventede kaptajnen hjemme igen: »Men at Hohlmann uden nogen foregaaende Forespørgsel saaledes have quitert Java og overladt samme til en anden Mand, som man dog ikke ret ved, hvor megen Tiltro man kan have til, dette er jo heller ikke i sin Orden, og har i det mindste ikke mit Bifald, og hvorledes maa han skulde være kommen overens med Mandskabet, thi disse pleier jo ved saadanne Leiligheder at opstaa på Benene og fordre en overdreven høy Løn." Jes Peter Boysen vidste dog intet, men ærgrede sig endnu en gang over at have overdraget Java til en mand, der viste sig så ligeglad og umeddelsom som Christian Hohlmann, hvis handlinger burde få konsekvenser: »thi en saadan Opførsel fortiener sandeligen en stor Dadel." (15. april 1865).

Den 1. maj havde Jes Peter Boysen haft et kort besøg af Christian Hohlmann, som få dage forinden var ankommet til Løjt. Kaptajnen havde sagt, at han ville til Sønderborg for at aflægge regnskab, hvilket Jes Peter Boysen gerne ville kende resultatet af, for at han kunne opgøre sit økonomiske mellemværende med ham. Den 10. maj forelå 
der endnu intet regnskab fra Hohlmann, men Jes Peter Boysen ville dog heller ikke involveres i dette forhold: »ei heller ønsker jeg at have noget med hans Regnskab at bestille, da ieg har fuldkomment nok indstrueret ham i denne Retning, imedens han foer med mig, og ieg haabede og troede, at min Umage ikke skulde have været spildt «. Jes Peter Boysens umage havde efter alt at dømme været spildt, og forbruget om bord på Java var ikke til at gennemskue ud fra de oplysninger, Hohlmann fremlagde.

Den 10. juni kunne Jes Peter Boysen meddele Iversen følgende: "Chr. Hohlmann var for et par Dage siden hos mig med sit Regnskab, men samme er endnu i selvsamme Tilstand, som dengang han var $i$ Sønderborg sidst, ieg kan og vil ikke have noget dermed at giøre, og det er sandelig heller ikke nogen let Opgave at omdanne et saadant Regnskab til et nogenlunde rigtigt og forstaaeligt, men ieg ville hermed bede Dem kiere Iversen, at De ville have den Godhed at hielpe ham til Rette dermed«. Et par af regnskabets uklarheder havde Christian Hohlmann kunnet forklare Jes Peter Boysen, »og saaledes vil meget opklare sig, naar Hohlmann selv er til stede ved Ordningen af Regnskabet, thi at Hohlmann har villet narre os, eller at han har villet forfordele sig selv en Nemst \$ [ville stikke en ekstra dollar til sig], dette maae vi ikke troe om ham, men derimod at Lodser, Dampbaadsfører, Skibshandlerer osv. har havt den bedste Fordel af Java siden ieg forlod samme, dette er soleklart, og værst for $\mathrm{H}$ : selv, da han har den største part Part, ieg troer, vi kan være glad ved, at han er kommen hiem.« (10. juni 1865).

Mens Christian Hohlmann ikke nød nogen stor respekt hos Jes Peter Boysen, så var Jes Andresens stjerne stigende: »leg talede forleden Dag med Capt. Chrestensen, som nyeligen er hjemkommet med Barkskibet Congo, og som var Matros med Andresen i den Tid, han var fører af Skibet Cherusker, han roste ham i alle Henseender, og enhver som kender ham hersteds giver ham samme Lag, at han faldt i Unaade hos Agent Bruhn og blev afskediget, har vel ikke saa meget at betyde, da min egen Svigerfader tillige med flere andre som i sin Tiid foor for dette Contor have havt samme Skiebne, saa ieg haaber, at vi vil finde os tilfreds med denne Mands Handlemaade « (1. maj 1865). Jes Peter Boysen følte sig vist heller ikke selv helt retfærdigt behandlet af Jørgen Bruhn i forbindelse med Cantons forlis, så han vidste, hvad han talte om. Snart begyndte brevene fra kaptajn Jes Andresen at komme med jævne mellemrum indeholdende orienteringer om Javas sejlads. 


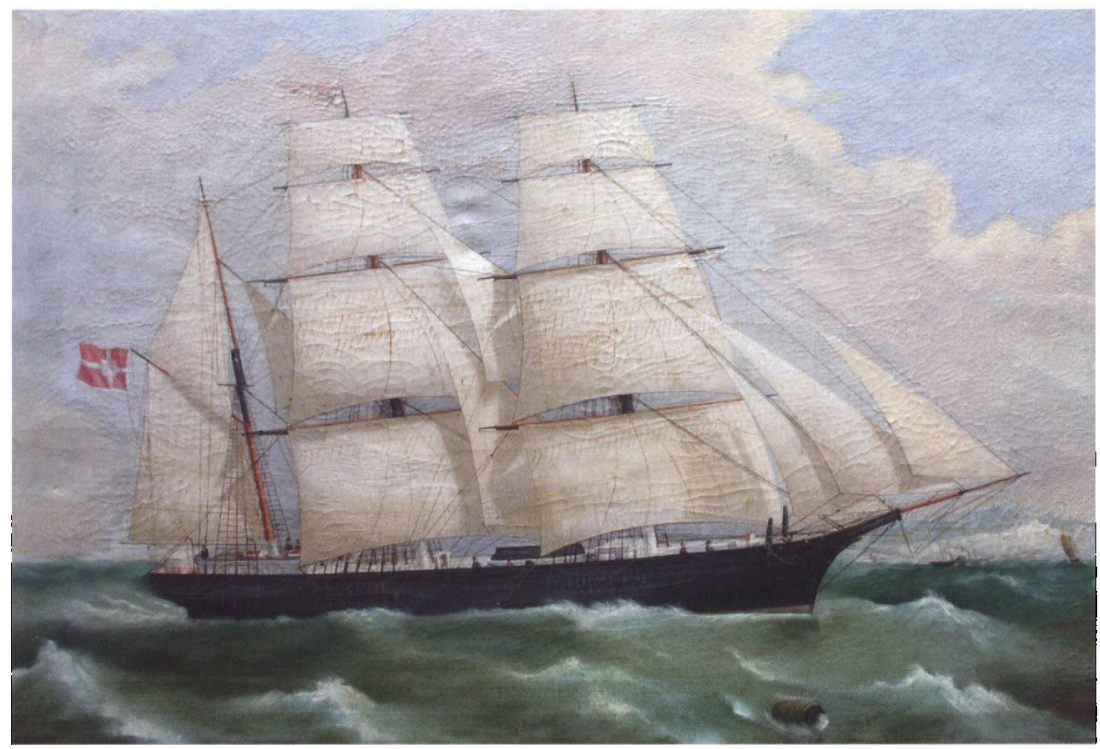

Usædvanligt stort skibsportræt af Java uden angivelse af kunstner og tidspunkt for dets tilblivelse. Det må dog vare malet senest $i$ 1864, da det endnu forer Dannebrog. Sammenholder man det forhold med, at skibsportrættet har været $i$ Rasmussen-familiens eje - kaptajn Jens Rasmussen var Jes Peter Boysens svigerson - synes det overvejende sandsynligt, at dette billede har varet $i$ Jes Peter Boysens eje. Det ser ud til, at skibet er på vej igennem Den Engelske Kanal med Dovers hvide skrænter $i$ baggrunden. Foto: Museum Senderjylland - Kulturhistorie Aabenraa.

I slutningen af juni kunne Jes Peter Boysen meddele Christian Karberg, at han havde haft Christian Hohlmanns regnskabsbog hos sig og kunne identificere to hovedproblemer. Det ene var, at kaptajnens egne udgifter til dels var blandet med skibets udgifter. Det andet var, at han "ikke har ofret meget paa Skibets vedligeholdelse", til trods for at han havde brugt mange penge (26. juni 1865). I september, hvor regnskabet endnu ikke er blevet afsluttet, fortæller Jes Peter Boysen om et yderligere problem med regnskabsførelsen: "fra de to første Reiser fra Shanghai findes der slet ingen Bilagsregninger «. Kaptajnen kunne simpelthen ikke dokumentere, hvad han havde brugt skibets penge på (19. september 1865). På grund af problemerne med regnskabet kunne Jes Peter Boysen i december fortælle, at han endnu ikke var klar over, hvad han havde tjent på Java i de $21 / 4$ år, der var gået, siden han afleverede skibet til Hohlmann (6. december 1865). 
Ved årsskiftet 1865/66 gjorde Jes Peter Boysen status over Javas situation, og den så angiveligt ikke god ud. For det første havde Jes Andresen kun fået en mindre fragt i efteråret, og skibet lå nu stille. For det andet havde skibet haft »frygtelig store Regninger «, men kaptajnen lovede, at de ikke ville blive så store fremover. Det tvivlede Jes Peter Boysen på, og han forventede ikke noget overskud af Java i fremtiden: wat skibets Garnering [den indre beklædning af lastrummet] skulle allerede være raaden, er jo meget slemt, dog troer ieg gierne, at det virkelig forholder sig saaledes, thi naar Ballasten ikke engang imellem er bleven skiftet og Garneringen reengiord og udtøret derunder, saa kan det $\mathbf{i}$ Sandhed ikke være anderledes, men der var intet Tegn til, at Garneringen havde lidt det allermindste af Ballasten, da ieg forlod Skibet i London, da der under min førelse af Skibet, blev sørget for sammes Conservation $i$ alle Maader, og ieg kalder det en frygtelig Ligegyldighed, at der ikke er bleven bedre sørget for dette gode Skib, med Mandskab ombord og Tiid og Lejlighed har der været nok dertil« (23. december 1865). Det var således ikke blot regnskaberne, der ikke var blevet passet ordentligt, mens Christian Hohlmann havde været kaptajn for Java, det var selve skibet tilsyneladende heller ikke. Af et senere brev fremgår det, at Jes Peter Boysen nu tilbød Christian Karberg sin sjettedel i skibet. Dette tilbud blev dog afslået (9. januar 1866).

\section{Det endelige opgør}

Den 8. januar 1866 kom Christian Hohlmann på besøg i Dyrhave hos Jes Peter Boysen, som dagen efter rapporterede indholdet af deres samtale til Christian Karberg. Den gamle kaptajn havde uden omsvøb meddelt Hohlmann, at han ikke skulle gå i den tro nogensinde igen at betræde Java som skibets fører. Efter den store ligegyldighed han havde udvist på den seneste rejse, kunne hans to medredere ikke tillade, at han fortsatte. Hohlmann havde medgivet, at han havde forset sig, men han mente dog ikke, at han havde handlet så slet, at han som ejer af halvdelen af skibet måtte renoncere på kaptajnsværdigheden. Ville de fastholde standpunktet, kunne de sælge ham hele Java, da hans søskende formentlig ville hjælpe ham. Jes Peter Boysen vidste, at en broder (formentlig tidligere omtalte Nis Hohlmann) og to søstre var formuende og ville være i stand til at hjælpe ham, hvis de holdt ord. Skulle det blive alvor, tvivlede han dog på, at de ville stå ved deres løfte, da de alle vidste, at Christian Hohlmann 
var en uduelig skibsfører, der ikke kunne føre et ordentligt regnskab, og som ikke omgikkes skibets penge med sparsomhed. Som modtræk havde en kaptajn Kiølseth tilbudt at købe Christian Hohlmanns halvdel, for at man uden videre kunne indsætte en ny fører, men Hohlmann ville kun sælge en kvart andel og det til en temmelig høj pris. En sådan handel ville ikke ændre forholdene for Java, så det ville Kiølseth ikke indlade sig på. Jes Peter Boysen foreslog, at dersom fragtmarkedet fortsat var dårligt, når Java ankom til Kinakysten, så skulle de have det hjem til Aabenraa, men denne beslutning overlod han til Christian Karberg (8. januar 1866).

Mødet mellem Jes Peter Boysen og Christian Hohlmann havde tydeligvis ikke været nogen venskabelig sammenkomst, men en direkte konfrontation, som først og fremmest var præget af de frustrationer, der havde hobet sig op hos den gamle kaptajn i de forgangne måneder. De to kan næppe være skiltes som venner, og mødet var endt uden en afklaring af, hvordan Java skulle ejes og føres $\mathrm{i}$ fremtiden.

Omtrent samme dag, hvor det skæbnesvangre møde fandt sted, afsendte Margrethe Boysen et brev til sin fader Jes Peter Boysen. Brevet er ikke bevaret, men hensigten var - som det fremgik af det indledningsvist citerede svarbrev - at få faderens velsignelse til at gifte sig med Christian Hohlmann! Brevet nåede frem den 13. januar, og Jes Peter Boysen må være blevet temmelig oprevet over dets indhold. Man må forestille sig, at han på den ene side var helt sikker på, at han ikke ønskede at få Christian Hohlmann som svigersøn, men på den anden side ønskede han vel heller ikke at gøre sin datter ked af det. Det sidste hensyn måtte dog vige for det første - samtidig var han tydeligvis overbevist om, at Hohlmann på lang sigt ikke ville være god for hende.

For Jes Peter Boysen synes konflikten med Christian Hohlmann dog aldrig at have været personlig. Det fremgår tydeligt af brevbøgerne, at Jes Peter Boysen ikke havde noget at udsætte på Christian Hohlmanns person eller karakter - hvilket han også skriver til Margrethe. Han havde ikke alene anbefalet ham som kaptajn for Java, men han skriver også, at Hohlmann var retskaffen og havde kundskaber. Der, hvor den gamle og den unge kaptajn adskilte sig, var med hensyn til deres udførelse af kaptajnsrollen. Jes Peter Boysen var alvorlig, pligtopfyldende og meddelsom - i brevbøgerne kan man se, at informationerne flød $i$ en lind strøm hjem til hans forskellige redere. Han var stolt af sine skibe, som han passede og plejede, så godt han kunne. Christian Hohlmann tog mere let på tingene. Det største 


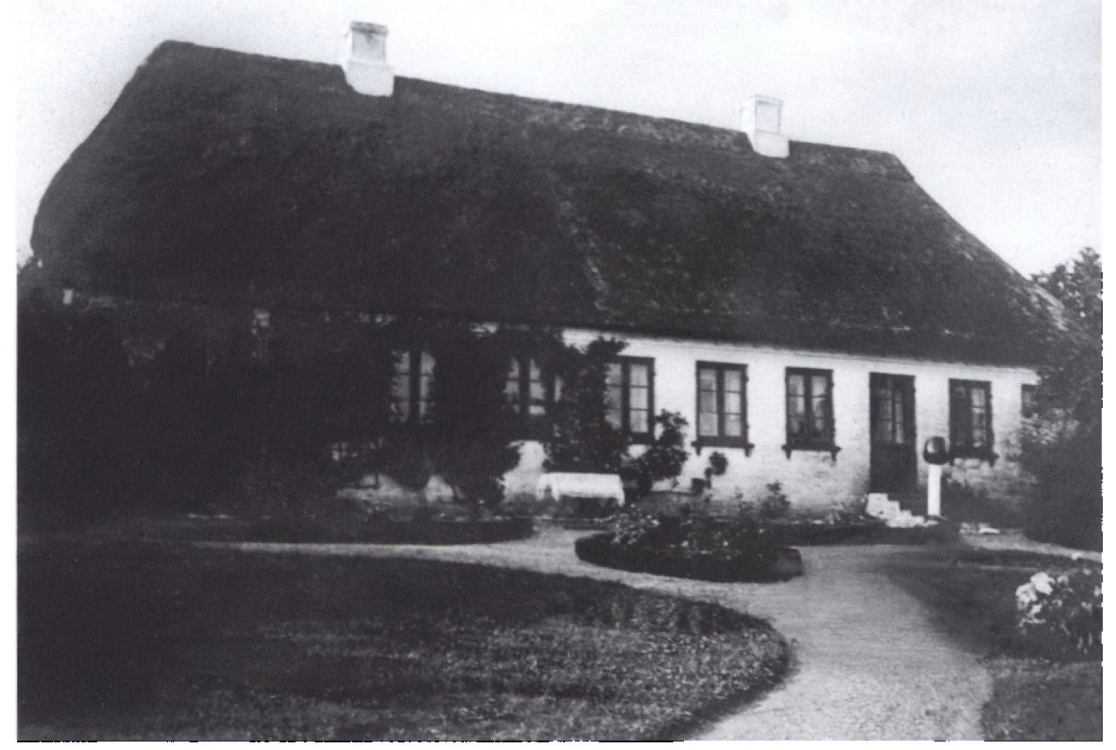

Gammelt fotografi af Jes Peter Boysens stråtækte kaptajnsgård i Dyrhave. Vender fotografen sig 180 grader om, har han en af de bedste udsigter over Aabenraa Fjord. Den kan den gamle kaptajns efterkommere, der endnu bebor gården, nu nyde. Foto: Privat.

problem var ifølge Jes Peter Boysen, at Christian Hohlmann ikke orienterede sine medredere om skibets sejlads og forretninger. Dertil kom andre svigt, der fremstår mindst lige så alvorlige. Det drejede sig om et for stort pengeforbrug fra skibets kasse, utilstrækkelig regnskabsføring og mangelfuld vedligeholdelse af skibet. For at bruge Jes Peter Boysens terminologi, så forstod Christian Hohlmann ikke at varetage skibets interesse, og derfor var han ingen duelig skibsforer.

Jes Peter Boysens problem med Christian Hohlmann var således af forretningsmæssig karakter, og derfor handler brevet til Margrethe også om, hvorledes den unge mand ville få vanskeligt ved at forsørge familien, når han ikke længere kunne få hyre som kaptajn. Det var de barske, men uomgængelige realiteter, som Jes Peter Boysen her stillede op for sin datter. Det er ikke sikkert, at hun kendte til problemerne med Java, så måske troede hun, at hun havde gjort et godt parti - Christian Hohlmann var jo ikke bare kaptajn, men også medreder for det store sejlskib og faderens kompagnon.

Forlovelsen mellem de to blev efter alt at dømme ikke til noget! 

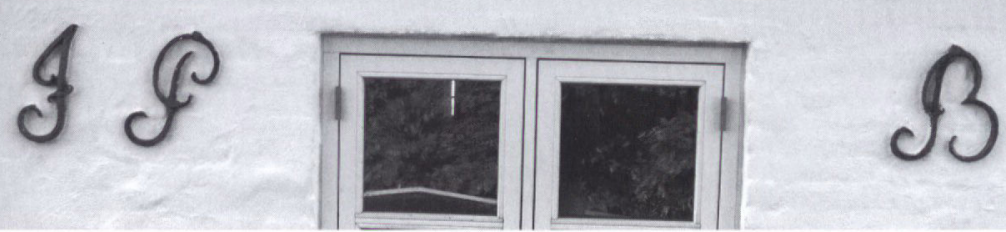

Jes Peter Boysens initialer på gavlen af hans gamle kaptajnsgård. De viser, at han byggede om på gården $i$ anden halvdel af 1860'erne. Måske var det ligefrem ham, der opferte den endnu stående bygning. Foto: Mikkel Leth Jespersen.

\section{Eftertiden}

Allerede i foråret 1866 lykkedes det Jes Peter Boysen at sælge sin sjettedel i Java til Christian Karbergs forretningsfører hr. Iversen i Sønderborg for 5.000 mark. (17. april 1866). På seks år var skibets værdi således faldet fra 60.000 til 30.000 mark. Under den tysk-franske krig blev Java oplagt i Hongkong og kondemneret i 1871.

Jes Peter Boysens svindende interesse for Java hang ikke blot sammen med forholdet til Christian Hohlmann, men var også influeret af, at han i 1865 havde investeret sine sparepenge i et andet skib. Det var skibet Therese, som hans svoger Hans Matthiessen (Stentoft) fik bygget på Paulsens værft i Aabenraa, og som løb af stablen omkring 1. september. Investeringen $i$ det nye skib blev omtalt i korrespondancen med Karberg, fordi den forudsatte, at Jes Peter Boysen hævede nogle penge, han havde stående hos Karberg. En del skulle betales, når skibet løb $\mathrm{i}$ vandet, og den sidste termin skulle falde, når skibet forlod byen (1. maj 1865). Senere fortælles det, at udbetalingen af pengene senest skulle ske den 8 . september, da skibet til den tid skulle være lobet af stabelen (28. august 1865). Der er ingen korrespondance vedrørende driften af Therese i Jes Peter Boysens brevbog, så mon ikke han overlod ansvaret til Hans Matthiessen og nød sit otium i Dyrhave. Den 3. marts 1865 havde han indleveret sit borgerbrev og sit skibscertifikat i Aabenraa, så hans tid som kaptajn var ovre. I 1873 blev han enkemand, men selv levede han frem til 1891 og nåede således at opleve Aabenraa-søfartens afvikling, efterhånden som træskibsværfterne lukkede, og de sidste sejlskibe blev afhændet $i$ anden halvdel af 1880 'erne.

Hvordan det gik Christian Hohlmann, efter at forlovelsen med Margrethe Boysen gik i vasken, er uvist. Han optræder ikke som kap- 
tajn for flere Aabenraa-skibe og er hverken at finde i kirkebøgerne for Løjt eller Aabenraa, så han forlod formentlig området, og sporene er visket bort. Jes Andresen fortsatte som kaptajn for Java i de efterfølgende år.

Margrethe blev derimod boende på Løjt, og i 1874 blev hun gift med sin fætter Claus Clausen. Ham omtalte Jes Peter Boysen også i sin brevbog $\mathrm{i}$ forbindelse med, at han anbefalede ham for Christian Karberg i 1865: "Skulle du i løbet af Vinteren mangle en Styrmand, saa kan ieg anbefale Dem min Sødster Søn Claus Clausen, han var Andenstyrmand [på] sidste Reise med Helvetien, [med] min Broder [som kaptajn], og var igien forgiort som Oberstyrmand med samme Skib, men da Skibet imidlertid blev solgt i Hamborg, saa er han for Øieblikket uden Employ, vil du have den Godhed at have ham i Erindring, han er en meget ret og duelig Mand og fortienner at forfremmes." (23. december 1865). Inden Christian Karberg nåede at reagere på anbefalingen, fik Claus Clausen dog hyre på Hans Matthiessens skib, opkaldt Boy Bendixen efter rederens svigerfader, som igennem mange år havde været en dygtig og respekteret kaptajn i Aabenraa (17. april 1866). Parret slog sig ned i Skarrev på Løjt Land, hvor Margrethe boede med deres fire børn, mens Claus Clausen sejlede på verdenshavene. Han blev blandt andet kaptajn om bord på barken Concordia, som var det sidste store sejlskib, der blev bygget i Aabenraa. Det oplyses, at han døde i nærheden af Skt. Helena på en rejse fra Sidney til Hamborg. Margrethe levede frem til 1913. ${ }^{15}$

Den yngre søster Ellen blev for øvrigt gift med kaptajn Jens Rasmussen (1847-1929), som i en årrække førte Aabenraa-skibet Sampan på Kinakysten. ${ }^{16}$ I det sidste brev i kopibogen fortæller Jes Boysen, hvordan det unge par fik hans velsignelse til at blive forlovet. Og da nogen havde tænkt ilde om deres færden i forbindelse med forlovelsen, forsvarede han dem. Beskrivelsen står således i stærk kontrast til afvisningen af Christian Hohlmann knap et årti tidligere. Samtidig giver den et stemningsfuldt indtryk af, hvordan sådanne store beslutninger blev taget, mens skibet lå sejlklart på fjorden, parat til at adskille de nyforlovede $\mathrm{i}$ årevis. Blev skibet af en eller anden grund liggende en ekstra nat, kunne de nyforlovede få endnu en dyrebar tid sammen, som måske blev den sidste:

»Da Ellen blev forlovet med Jens laae Skibet ganske seilfærdig paa Rheden, endskiøndt Jens ofte var kommen i mit Huus for Bekjendtskabs Skyld med mine Sønner, varer [kendte] ieg ikke hans Hensigt, 
det var mig en Overraskelse, da Ellen om Aftenen tiltalede mig omtrendt saaledes: Father ieg har noget at sige dig, Jens Rasmussen har friet til mig, og ieg maa endnu i aften til Apenrade for at give ham mit Ja, hvis du ellers ikke har noget derimod, ieg svarede derpaa, at dette var mig kiert, og bad [hende] at hilse Jens, og hvis det var muligt, ieg gierne ønskede at tale med ham før Afseilingen, Skibet skulle seile næste dags Morgen, for Vinden havde vært god, af denne Aarsag kom Jens og Ellen denne Nat igennem Skoven op til vort Haus og begiert [bad om faderens velsignelse], saa det tilkommer mig at forsvare en sådan Gjerning. Tidlig om Morgenen seiledt mine Drenge ham til Skibet, og da samme ikke kom til at seile denne Dag, hentede de ham igen her og om Aftenen, hvor de da igien om [?] kiørte til Kierkebye $\mathrm{i}$ vores Vogn, ved saadanne natlige Vandringer kan der efter min Mening ikke være noget usømmeligt eller uanstændigt, lad Verden nu kun sige derom, hvad den ville, denne dømmende Dadel eller Bifald bekymre ieg mig slet ikke noget om« (5. februar 1875).

\section{KILDER OG LITTERATUR}

Utrykt kildemateriale:

Skibslister 1829-1843 og 1846-1847, Aabenraa Kobstad, pk.nr. 165E, Landsarkivet for Sønderjylland.

Kaptajn Jes Peter Boysens kopibøger, Sofartssamlingen, pk.nr. 1, Landsarkivet for Sønderjylland.

Litteratur og trykte kilder:

Becker, Bert: Michael Jebsen 1835-1899. Reeder und Politiker, Kiel 2012.

Holdt, Jes M.: Gårde og Slagter i Lajt sogn, Aabenraa 1982.

Holm-Petersen, F.: Under sejl i fjernestlige farvande, Norderstedt 1975.

Japsen, Gottlieb: Den nationale udvikling i A benra 1800-1850, Tronder 1961.

Jespersen, Mikkel Leth og Stefanie Robl Matzen (red.): Sønderjyder fortæller SØFARTSHISTORIER $i$ anledning af Aabenraa Museums 125-års jubilæum, Aabenraa 2012.

Knudsen, Niels: Senderborg Skipperlaug 1571-1971, Sønderborg 1970.
Larsen, Rolf: »Fregatskibet »Creole« af Aabenraa (1825-1850)«, i: Søfart selvfolgelig! Festskrift $i$ anledning af Aabenraa Museums 125-års jubilæum, Aabenraa 2012.

Manden der red på en delfin. Kaptajn Hans Bruhns erindringer, Karen Harder Lildholdt og Claus Lildholdt (udg.), Aabenraa 2008.

Mercantil-Calender for det danske Monarchie for 1862 udgivet af Julius Erichsen, Kobenhavn.

Nielsen, Erik Møller: Fra Klamp til Konstruktion. Fra håndvark til ingeniorkunst $i$ Aabenraa's sejlskibsbyggeri ca. 1800-1880, Aabenraa 2000.

Verzeichniss der Schleswig-Holsteinischen Rhederei ult. 1864. Nach officiellen $Q u-$ ellen zusammengestelltes Verzeichniss aller in Schleswig-Holstein zu Hause gehörenden Schiffe von 10 Lasten und darüber, in alphabetischer Reihenfolge untischer Reihenfolge und districtsweise geordnet, Kiel 1865. 
NOTER

1. Jes Peter Boysens to brevbøger, der befinder sig i Sofartssamlingen på Landsarkivet for Sønderjylland, udgor hovedparten af kildematerialet til denne artikel. Den første brevbog dækker perioden 1849-1856, den anden perioden 1856-1875. I artiklen henvises der til brevene ved deres datering.

2. Skibslister Aabenraa, diverse årgange.

3. Se f.eks. Japsen 1961, s. 58.

4. Om skibet Creole se Larsen 2012.

5. Hans Bruhn, s. 60.

6. Holdt 1982, s. 292.
7. Knudsen 1970, s. $104 \mathrm{f}$.

8. Holdt 1982, s. 47.

9. Nielsen 2000, s. 184.

10. Mercantil-Calender 1862.

11. Verzeichniss der Schleswig-Holsteinischen Rhederei ult. 1864.

12. Holm-Petersen 1975; om Java specifikt se s. 132.

13. Becker 2012, s. 320.

14. Knudsen 1970 , s. 89.

15. Om faderen Jep Hansen Schmidts død: se Jespersen og Matzen 2012, s. 36.

16. Holdt 1982, s. 130.

17. Holdt 1982, s. 292.

\section{Zusammenfassung}

Das Leben zur See war dicht mit dem Leben daheim verbunden. Das bekam der Kapitän Christian Hohlmann zu fühlen, als ihm sein Verwalten des Schiffes Java im Jahr 1866 die Verlobung mit seiner Auserwählten kostete. Es verhielt sich nämlich so, dass der Vater des Mädchens, Kapitän Jes Peter Boysen aus Dyrhave auf Løjt, der als Mitreeder an der Java beteiligt war, keineswegs mit Hohlmann zufrieden war. Die Geschichte kann man in einem der Briefebücher von Jes Peter Boysen nachlesen und so einen guten Einblick in die Verhältnisse bekommen, die einen guten Segelschiffkapitän ausmachen. Neben Navigation und Instandhaltung des Schiffes sollte er auch das Schiff geschäftsmäßig führen können und die (Mit)Reeder über seine Dispositionen unterrichtet halten. "Ein tauglicher Kapitän”, so hieß es im Buch mit den Briefen, solle die "Interessen des Schiffes" wahrnehmen können. Die verhältnismäßig dramatische Erzählung von einer aufgegebenen Verlobung bildet somit den Eingang zu zentralen Aspekten in der Seefahrtkultur des 19. Jahrhunderts. 
